\title{
Erratum to: Framenau, V.W. 2006: The wolf spider genus Venatrix Roewer: new species, synonymies and generic transfers (Araneae, Lycosidae) \\ (Records of the Western Australian Museum 23: 145-166)
}

\author{
Volker W. Framenau \\ Department of Terrestrial Invertebrates, Western Australian Museum, \\ Locked Bag 49, Welshpool D.C., Western Australia 6986, Australia
}

The species description of Venatrix amnicola Framenau, 2006 did not include a diagnosis for this species as it was accidentally omitted during the editing process; a mistake for which the author takes full responsibility. To follow recommendation $13 \mathrm{~A}$ of the International Code of Zoological Nomenclature (International Commission on Zoological Nomenclature 1999) and to facilitate identification of the species a diagnosis for $V$. amnicola is here given to differentiate it from the similar species $V$. arenaris (Hogg, 1905) and $V$. palau Framenau, 2006. This diagnosis should be placed between the listing of types and the etymology in the description of $V$. amnicola (Framenau 2006: 146).

\section{Diagnosis of $V$. amnicola}

Venatrix amnicola is closely related to $V$. arenaris (Hogg, 1905) and V. palau sp. nov., however, the carapace markings of $V$. palau distinctly differ from the two other species as the edges of the median band are much smoother. Venatrix palau is also distinctly smaller. Males can be distinguished by the shape of the terminal apophysis of the pedipalp, which is very broad in $V$. arenaris with a basally bent and sharp tip (see Framenau et al. 2006). It curves around the tip of the embolus in $V$. palau but forms a triangle with a tip being round and ventrally bent in $V$. amnicola. There do not appear to be any somatic or genitalic features that clearly separate females of $V$. amnicola and $V$. arenaris. The posterior transverse part of the epigyne may differ between both species as it is generally thinner and the lateral edges are generally yellowish-white in $V$. arenaris but broad and not lighter at the edges than in the other areas of the posterior transverse part in V. amnicola.

\section{REFERENCES}

Framenau, V.W. (2006). The wolf spider genus Venatrix Roewer: new species, synonymies and generic transfers (Araneae, Lycosidae). Records of the Western Australian Museum 23: 145-166.

Framenau, V.W., Gotch, T.B. and Austin, A.D. (2006). The wolf spiders of artesian springs in arid South Australia, with a revalidation of Tetralycosa (Araneae, Lycosidae). Journal of Arachnology 34: 136.

International Commission on Zoological Nomenclature (1999). International Code of Zoological Nomenclature. International Trust for Zoological Nomenclature: London.

Manusript received 27 February 2007; accepted 21 March 2007 


\section{CONTENTS VOLUME 23}

\section{Part 1}

\section{H.S. Gill, D.L. Morgan, R.G. Doupé and A.J. Rowland}

The fishes of Lake Kununurra, a highly regulated section of the Ord River in

northern Western Australia

David L. Morgan, Andrew Chapman, Stephen J. Beatty and Howard S. Gill

Distribution of the spotted minnow (Galaxias maculatus (Jenyns, 1842))

(Teleostei: Galaxiidae) in Western Australia including range extensions and sympatric species

Mark S. Harvey

A new species of Lechytia from eastern Australia (Pseudoscorpiones: Lechytiidae)

R.G. Gunn

Mulka's Cave Aboriginal rock art site: its context and content

\section{L.B. Bean}

The leptolepid fish Cavenderichthys talbragarensis (Woodward, 1895) from the Talbragar

Fish Bed (Late Jurassic) near Gulgong, New South Wales

D. Franklin and L. Freedman

A bioarchaeological investigation of a multiple burial associated with the Batavia mutiny of 1629

Jan L. den Blaauwen, Richard E. Barwick and Kenton S.W. Campbell

Structure and function of the tooth plates of the Devonian lungfish Dipterus valenciennesi from Caithness and the Orkney Islands 


\section{Part 2}

\section{R.E. Johnstone}

The birds of Gag Island, Western Papuan islands, Indonesia

David L. Morgan and Howard S. Gill

Osteology of the first dorsal fin in two terapontid fishes, Leiopotherapon unicolor

(Günther, 1859) and Amniataba caudavittata (Richardson, 1845), from Western Australia:

evidence for hybridisation?

\section{Volker W. Framenau}

The wolf spider genus Venatrix Roewer: new species, synonymies and generic transfers (Araneae, Lycosidae)

\section{Mark S. Harvey}

New species and records of the pseudoscorpion family Menthidae (Pseudoscorpiones)

\section{Brian Morton}

The functional morphology of Penicillus philippinensis (Anomalodesmata:

Clavagelloidea: Penicillidae) and the evolution of an unique muscular system in the Bivalvia

\section{Gregory D. Edgecombe}

A troglobitic cryptopid centipede (Chilopoda: Scolopendromorpha) from western Queensland

Mark S. Harvey, Frantisek Štáhlavský and Pieter D. Theron

The distribution of Eukoenenia mirabilis (Palpigradi: Eukoeneniidae): a widespread tramp

Mark S. Harvey and Lee G. Mould

A new troglomorphic species of Austrochthonius (Pseudoscorpiones: Chthoniidae)

from Australia, with remarks on Chthonius caecus 


\section{Part 3}

\section{Nadine A. Guthrie}

A new species of Gnathoxys (Coleoptera: Carabidae: Carabinae) from an urban bushland remnant in Western Australia

\section{Terry F. Houston}

Observations of the biology and immature stages of the sandgroper Cylindraustralia kochii (Saussure), with notes on some congeners (Orthoptera: Cylindrachetidae)

Scott A. Thompson and Graham G. Thompson

Temporal variation in ground-dwelling invertebrate biomass in the Goldfields of Western Australia

Paul Doughty and Marion Anstis

A new species of rock-dwelling hylid frog (Anura:Hylidae) from the eastern

Kimberley region of Western Australia

\section{Marion Anstis, J. Dale Roberts and Ronald Altig}

Direct development in two Myobatrachid Frogs, Arenophryne rotunda Tyler and Myobatrachus gouldii Gray, from Western Australia

Brad Maryan, Ken P. Aplin and Mark Adams

Two new species of the Delma tincta group (Squamata: Pygopodidae) from northwestern Australia

\section{SHORT COMMUNICATION}

\section{Justin A. Chidlow}

First record of the freshwater sawfish, Pristis microdon, from southwestern

Australian waters

\section{Part 4}

\section{L.A. Smith and M. Adams}

Revision of the Lerista muelleri species group (Lacertilia: Scincidae) in Western Australia, with a redescription of $L$. muelleri (Fischer, 1881) and the description of nine new species

Ilse Bartsch

Halacarid mites (Acari: Halacaridae) from Esperance, Western Australia: Notes on taxonomy and faunal distribution of non-Copidognathinae

Mark S. Harvey, Julianne Waldock, Roy J. Teale and Jenni Webber

New distribution records of the intertidal pseudoscorpion Parahya submersa

(Pseudoscorpiones: Parahyidae)

\section{Harry Smit}

The water mite genus Recifella from Australia (Acari: Hydrachnidia: Unionicolidae)

\section{Volker W. Framenau}

Erratum to: Framenau, V.W. 2006: The wolf spider genus Venatrix Roewer: new species, synonymies and generic transfers (Araneae, Lycosidae)

(Records of the Western Australian Museum 23: 145-166) 
Adams, $M$. 273,309

Altig, R.

Anstis, M.

241, 259

Aplin, K.P.

Bartsch, I.

Barwick, R.E.

Bean, L.B.

Beatty, S.J.

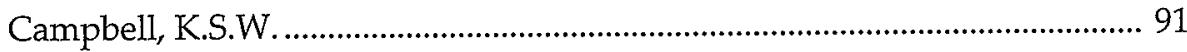

Chapman, A.

Chidlow, J.A

den Blaauwen, J.L.

91

Doughty, P.

Doupé, R.G.

Edgecombe, G.D.

Framenau, V.W

Franklin, D. 77

Freedman, L.

Gill, H.S. $1,7,133$

Gunn, R.G. 19

Guthrie, N.A. 213

Harvey, M.S. $13,167,199,205,393$

Houston, T.F. 219

Johnstone, R.E. 115

Maryan, B. 273

Morgan, D.L. $1,7,133$

Morton, B. 175

Mould, L.G. 205

Roberts, J.D. 259

Rowland, A.J ... 1

Smith, L.A.

Smit, H. 397

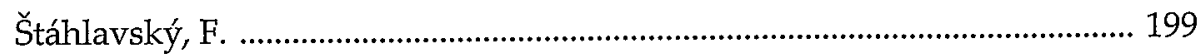

Teale, R.J. 393

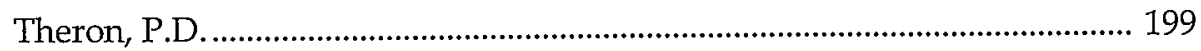

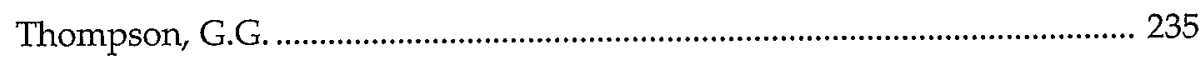

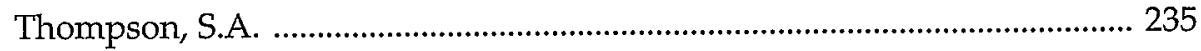

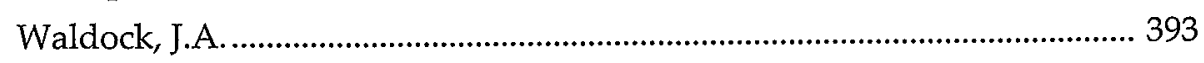

Webber, $\mathrm{J}$. 


\section{Guide to Authors}

\section{Subject Matter:}

Reviews, observations and results of research into all branches of natural science and human studies will be considered for publication. However. emphasis is placed on studies pertaining to Western Australia. Longer papers will be considered for publication as a Supplement to the Records of the Western Australian Museum. Short communications should not normally exceed three typed pages and this category of paper is intended to accommodate observations, results or new records of significance. that otherwise might not get into the literature, or for which there is a particular urgency for publication. All material must be original and not have been published elsewhere.

\section{Presentation:}

Authors are advised to follow the layout and style in the most recent issue of the Records of the Western Australian Museum including headings, tables, illustrations and references.

The title should be concise, informative and contain key words necessary for retrieval by modern searching techniques. An abridged title (not exceeding 50 letter spaces) should be included for use as a running head.

An abstract must be given in full length papers but not short communications, summarizing the scope of the work and principal findings. It should normally not exceed $2 \%$ of the paper and should be suitable for reprinting in reference periodicals.

The International System of units should be used.

Numbers should be spelled out from one to nine in descriptive text; figures used for 10 or more. For associated groups, figures should be used consistently, e.g., 5 to 10 , not five to 10 .

Spelling should follow the Concise Oxford Dictionary.

Systematic papers must conform with the International Codes of Botanical and Zoological Nomenclature and, as far as possible, with their recommendations.

Synonymies should be given in the short form (taxon, author, date, page) and the full reference cited at the end of the paper. All citations, including those associated with scientific names, must be included in the references.

\section{Manuscripts:}

The original and two copies of manuscripts and figures should be submitted to the Editor, c/ Publications Department. Western Australian Museum, Locked Bag 49, Welshpool DC, Western Australia 6986. They must be in double-spaced typescript on A4 sheets. All margins should be at least $30 \mathrm{~mm}$ wide. Tables plus heading and legends to illustrations should be typed on separate pages. The desired position for insertion of tables and illustrations in the text should be indicated in pencil. Tables should be numbered consecutively, have headings which make them understandable without reference to the text, and be referred to in the text.

High quality illustrations are required to size $(16.8 \mathrm{~cm} \times 25.2 \mathrm{~cm})$ or no larger than $32 \mathrm{~cm} \times 40$ $\mathrm{cm}$ with sans serif lettering suitable for reduction to size. Photographs must be good quality black and white prints, not exceeding $16.8 \mathrm{~cm} \times 25.2 \mathrm{~cm}$. Scale must be indicated on illustrations. All maps, line drawings, photographs and graphs, should be numbered in sequence and referred to as Figure/s in the text and captions. Each must have a brief, fully explanatory caption. On acceptance a computer disk containing all corrections should be sent with amended manuscript. The disk should be marked with program (e.g. Word, WordPerfect, etc).

In papers dealing with historical subjects references may be cited as footnotes. In all other papers references must be cited in the text by author and date and all must be listed alphabetically at the end of the paper. The names of journals are to be given in full.

\section{Processing:}

Papers and short communications are reviewed by at least two referees and acceptance or rejection is then decided by the editor.

The senior author is sent one set of page proofs which must be returned promptly.

The senior author will receive fifty free offprints of the paper. Additional offprints can be ordered at page proof stage. 


\section{Records of the Western Australian Museum Volume 23 Part 42007}

\section{CONTENTS}

\section{L.A. Smith and M. Adams}

Revision of the Lerista muelleri species-group (Lacertilia: Scincidae) in Western Australia, with a redescription of $L$. muelleri (Fischer, 1881) and the description of nine new species

\section{Ilse Bartsch}

Halacarid mites (Acari: Halacaridae) from Esperance, Western Australia:

Notes on taxonomy and faunal distribution of non-Copidognathinae

\section{Mark S. Harvey, Julianne Waldock, Roy J. Teale and Jenni Webber}

New distribution records of the intertidal pseudoscorpion Parahya submersa

(Pseudoscorpiones: Parahyidae)

\section{Harry Smit}

The water mite genus Recifella from Australia

(Acari: Hydrachnidia: Unionicolidae)

\section{Volker W. Framenau}

Erratum to: Framenau, V.W. 2006: The wolf spider genus Venatrix Roewer: new species, synonymies and generic transfers (Araneae, Lycosidae) (Records of the Western Australian Museum 23: 145-166) 